\title{
Unusual cause of mediastinal widening and atrial fibrillation: mediastinal lipomatosis with infiltration into the interatrial septum
}

\author{
Akash Batta (D) ,' Manphool Singhal (D) ,' Atit A Gawalkar (D) , \\ Parminder Singh Otaal (D) ${ }^{1}$
}

${ }^{1}$ Department of Cardiology, Post Graduate Institute of Medical Education and Research, Chandigarh, India ${ }^{2}$ Radiodiagnosis, Post Graduate Institute of Medical Education and Research, Chandigarh, India

Correspondence to Dr Parminder Singh Otaal; psotaal@gmail.com

Accepted 11 October 2021
Check for updates

(c) BMJ Publishing Group Limited 2021. No commercial re-use. See rights and permissions. Published by BMJ.

To cite: Batta A, Singhal M, Gawalkar AA, et al. BMJ

Case Rep 2021:14:e246980. doi:10.1136/bcr-2021-

246980

\section{DESCRIPTION}

A 40-year-old obese female with a history of hypothyroidism presented with palpitations at rest and shortness of breath for the past 1 year. Her thyroid functions had remained stable on $25 \mu \mathrm{g}$ levothyroxine for the last 2 years. The recently performed thyroid function test was within normal range with a thyroid-stimulating hormone of $2.2 \mathrm{mIU} / \mathrm{L}$ (range $0.5-5.0 \mathrm{mIU} / \mathrm{L}$ ), thyroxine of $7.5 \mu \mathrm{g} / \mathrm{dL}$ (range $4.8-12.7 \mu \mathrm{g} / \mathrm{dL}$ ) and triiodothyronine of $1.1 \mathrm{ng} / \mathrm{mL}$ (range $0.8-2.0 \mathrm{ng} / \mathrm{mL}$ ). Physical examination revealed an irregular pulse at 110 beats per minute with a pulse-apex deficit of 20 per

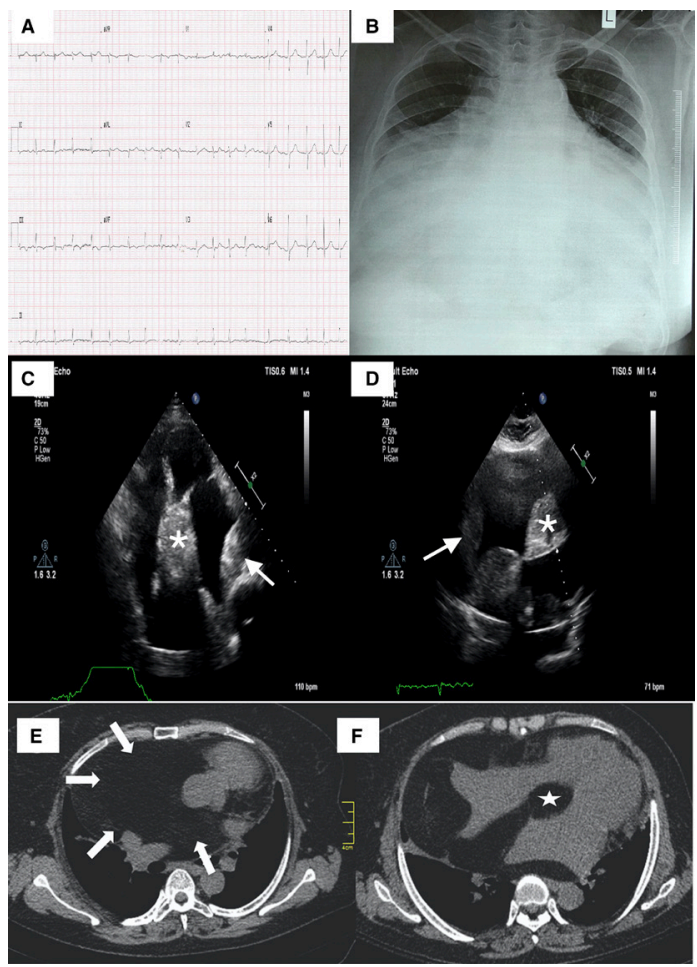

Figure 1 ECG showing atrial fibrillation with a controlled ventricular rate (A). Gross cardiomegaly and mediastinal widening noted on chest $\mathrm{X}$-ray (B). Transthoracic echocardiogram in apical four-chamber view (C) and subcostal view (D) showing mass-like lesion causing thickening of the interatrial septum (asterisk) and similar lesions abutting both the atria (white arrows). Non-contrast CT axial images show fat attenuation tissue in the mediastinum (arrows) (E). Note the lesion is extending into the interatrial septum (star) which is thickened (F).

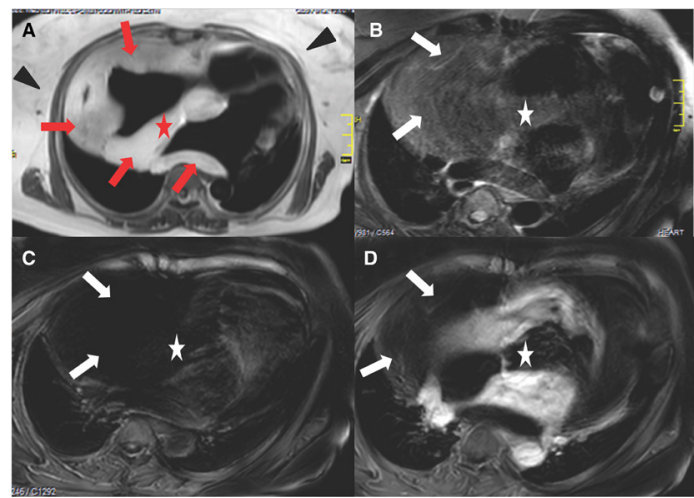

Figure 2 Cardiac magnetic resonance axial images show a hyperintense mass in the mediastinum (red arrows) on a double inversion recovery black blood image (A). The lesion has similar signal intensity as subcutaneous fat (black arrowheads). The lesion is hypointense on short tau inverse recovery (B) and exhibits loss of fat signal on T1 turbo spin echo (TSE) fat saturation (C) without enhancement on T1 TSE fat saturation images (D) (arrows). Note that the mass extends along the base of the heart, inferior surface and infiltrates the interatrial septum (red and white stars).

minute. On cardiac examination, the heart sounds were muffled. An ECG revealed atrial fibrillation (figure 1A). A chest X-ray showed cardiomegaly and mediastinal widening (figure $1 \mathrm{~B}$ ). Transthoracic echocardiography revealed a mass-like thickening of the interatrial septum along with a similar mass lesion abutting both the atria with biatrial dilatation (figure 1C,D). The possibility of a malignant cardiac tumour infiltrating the interatrial septum, the pericardium and the mediastinum was considered. CT revealed a fat attenuation tissue in the mediastinum extending from the superior mediastinum to the diaphragm. The lesion involved the pericardium and epicardium and extended into the interatrial septum (figure 1E,F). Cardiac magnetic resonance (CMR) imaging demonstrated a welldefined fat signal intensity mass (hyperintense on double inversion recovery black blood and hypointense on short tau inverse recovery), with loss of fat signal without enhancement on T1 fat saturation images (figure 2A-D). The mass encased all mediastinal vascular structures without luminal compromise. These characteristic findings were diagnostic of mediastinal lipomatosis. The biatrial dilatation on echocardiography was possibly related 
to the long-standing atrial fibrillation as there was only grade 1 left ventricular diastolic dysfunction and no evidence of mitral or tricuspid regurgitation. She was managed conservatively with beta-blockers and diuretics (when required) and is currently asymptomatic at 2 years of follow-up.

The usual causes of mediastinal widening include dilated cardiomyopathy, aortic dissection, lymphoma thymic malignancy, oesophageal injury and perforation, pericardial effusion, Ebstein's anomaly, chronic severe valvular regurgitation, trauma and mediastinitis. Mediastinal lipomatosis is a benign condition characterised by excessive deposition of adipose tissue within the mediastinum. It is most often related to primary Cushing's syndrome or iatrogenic chronic steroid therapy, hypothyroidism and obesity. ${ }^{1}$ Most cases are asymptomatic and diagnosis is usually made incidentally when chest X-ray is performed for other reasons. When symptomatic, the usual symptoms include dyspnoea most commonly, cough, atypical

\section{Patient's perspective}

I was worried when I was told about the suspicion of a mass in my chest, which was causing my irregular heart beat and shortness of breath. However, I felt relieved after the investigations revealed that it was all excess fat and not lifethreatening. Currently I am fine, but occasionally the irregular fast heart rate bothers me once in a while

\section{Learning points}

- Mediastinal lipomatosis is a benign condition characterised by excessive adipose tissue deposition in the mediastinum, resulting in mediastinal widening.

- Most cases are asymptomatic and picked up incidentally at the time of X-ray for other reasons.

- The commonly associated conditions include primary or iatrogenic Cushing's syndrome, hypothyroidism and obesity.

- CT and cardiac magnetic resonance explicitly confirm the diagnoses, obviating the need for biopsy or surgery.

- Most patients do well with conservative management, and surgery is rarely needed for severe compressive symptoms. chest pain and supraventricular tachycardia. ${ }^{12}$ Mediastinal lipomatosis with extension into the interatrial septum represents a rare cause of atrial fibrillation and mediastinal widening. Classical X-ray features include a smooth and lobulated widening of the upper mediastinum extending superiorly from the hilum to the tracheal deviation. Additional prominent epicardial fat and pleural widening at the apices of lungs may be noticed. ${ }^{2}$ Typical imaging features of fatty infiltration on CT and CMR explicitly confirm the diagnosis, obviating the need for histopathological confirmation. ${ }^{1-3}$ Most cases do well with conservative management with removal of the cause like Cushing's syndrome or iatrogenic steroid therapy, but surgery in the form of debulking may be needed in those with significant compressive symptoms. ${ }^{12}$ Precise knowledge and interpretation of imaging findings can help avoid unnecessary surgery, which is common in these patients. ${ }^{45}$

\section{Twitter Akash Batta@akashbatta02 and Atit A Gawalkar @atitag4}

Contributors $A B$ was involved in conceptualisation, methodology, investigation, supervision, original draft preparation, reviewing and editing. MS was involved in diagnosis, reviewing and editing. AG was involved in conceptualisation, methodology, investigation, supervision, original draft preparation, reviewing and editing. PSO was involved in supervision, reviewing and editing.

Funding The authors have not declared a specific grant for this research from any funding agency in the public, commercial or not-for-profit sectors.

Competing interests None declared.

Patient consent for publication Consent obtained directly from patient(s) Provenance and peer review Not commissioned; externally peer reviewed.

\section{ORCID iDs}

Akash Batta http://orcid.org/0000-0002-7606-5826

Manphool Singhal http://orcid.org/0000-0002-1311-7203

Atit A Gawalkar http://orcid.org/0000-0003-1625-7436

Parminder Singh Otaal http://orcid.org/0000-0001-8151-6452

\section{REFERENCES}

1 Nguyên KQ, Hoeffel C, Lê LH, et al. Mediastinal lipomatosis. South Med J 1998:91:1169-72.

2 Bulakci M, Yahyayev A, Ucar A, et al. Unusual cause of right ventricular outflow tract compression: mediastinal lipomatosis. J Thorac Imaging 2011;26:W134-6.

3 Gaerte SC, Meyer CA, Winer-Muram HT, et al. Fat-containing lesions of the chest. Radiographics 2002;22 Spec No:S61-78.

4 Nadra I, Dawson D, Schmitz SA, et al. Lipomatous hypertrophy of the interatrial septum: a commonly misdiagnosed mass often leading to unnecessary cardiac surgery. Heart 2004;90:e66

5 Bielicki G, Lukaszewski M, Kosiorowska K, et al. Lipomatous hypertrophy of the atrial septum - a benign heart anomaly causing unexpected surgical problems: a case report BMC Cardiovasc Disord 2018;18:1-6.

Copyright 2021 BMJ Publishing Group. All rights reserved. For permission to reuse any of this content visit

https://www.bmj.com/company/products-services/rights-and-licensing/permissions/

BMJ Case Report Fellows may re-use this article for personal use and teaching without any further permission.

Become a Fellow of BMJ Case Reports today and you can:

- Submit as many cases as you like

- Enjoy fast sympathetic peer review and rapid publication of accepted articles

- Access all the published articles

- Re-use any of the published material for personal use and teaching without further permission

Customer Service

If you have any further queries about your subscription, please contact our customer services team on +44 (0) 2071111105 or via email at support@bmj.com.

Visit casereports.bmj.com for more articles like this and to become a Fellow 